\title{
Radiation Hormesis: High-Radiation Dose Equivalents in Hot Springs Enhancing Curative Practices
}

\author{
Abdul-Wali Ajlouni \\ Naif Arab University for Security Sciences (NAUSS)-College of Forensic Sciences-Department of Forensic \\ Chemistry, Riyadh - Kingdom of Saudi Arabia
}

\begin{abstract}
The present study introduces records of radiation doses due to Natural Radioactivity measured in the investigations we have already carried out in various natural curative resources in Jordan, major of them include mineral and hot springs and the salt water and the volcanic mud of the Dead Sea. The investigated spots, in this study and other related studies, are located in Tafila, Irbid, Karak, and the Dead Sea. These data emphasis on new findings of different radiation dose rates, to identify the impacts of radiation exposures on public health. Using the assumption of radiation-Hormesis model about the astonishing effects of natural radiation doses, the author recommends that these doses existing in the investigated areas, improve the people health and increase average life span with less disease, and decrease incidence of cancer. This benefit will be added to promote health tourism, which have a tendency to be more active, and more competitive, where it challenges other kinds of tourism.
\end{abstract}

Key Words: Jordan, Hot springs, natural curative resources, natural radiation, radiation detection, absorbed dose rates, radiation hormesis.

\section{Introduction}

In Jordan there is a variety of natural curative resources, include mineral and hot springs and the salt water and the volcanic mud. These springs (Figure 1) are still used in curing many sicknesses such as arthritic, rheumatic, respiratory, neurological systems and skin diseases mainly Psoriasis. Major curative sites in Jordan include Ma'in, Al Hammah, North-Shuneh, Afra, Al Barbaitah, Wadi Bin Hammad, and the Dead Sea, the world largest natural spa with distinctive therapeutic properties that are never available elsewhere (Harahsheh, 2002). Hot springs, which usually used as spas by Jordanian and non-Jordanian visitors, are the major source of natural radionuclides and radiation doses for the public in this part of the country (AL-amairyeen 2010).

This paper aims to utilize the radiation Hormesis model assumptions, about the positive effects of natural radiation doses existing in the investigated areas, to improve the people health and to support health tourism.

\subsection{Radiation Hormesis}

The word hormesis is derived from the Greek word "hormaein" which means "to excite". Hormesis is any motivating or beneficial effect, induced by low doses of an agent, that can not be predicted by the extrapolation of detrimental or lethal effects induced by high doses of the same agent.

Luckey, a key investigator in radiation hormesis, gave evidences for that hormesis could be induced effectively by low doses of ionizing radiation. In 1980 the first complete statement on radiation hormesis was published. In this statement he reviewed numerous articles regarding radiation hormesis. Since that, thousands of papers have been published on the benefits of low doses of ionizing radiation. The concept of radiation hormesis is usually useful to physiological benefits from low Linear Energy Transfer (LET) radiation in the range of 10-500 mGy total absorbed dose (Macklis 1991). It is widely believed that radiation biology in the future will be very important issue to be studied, concentrating on problems of damage and repair, genetic implications on molecular scale which all related to radiation hormesis and radio-adaptive response.

\subsection{Radiation Hormesis and LNT Theory}

Despite the fact that high doses of ionizing radiation are harmful, extensive data from both humans and experimental animals show that biologic functions are stimulated by low radiation doses. Drinking mineral water containing radium was very popular. People went to spas to drink radioactive water or stayed for hours in caves to be irradiated by ionizing radiation. Surprisingly, until the end of World War II, ionizing radiation was considered a great scientific miracle. After the war the development of nuclear weapons and later increased use of nuclear power changed this great miracle into radio-fear. At that time people became scared of even very small doses of ionizing radiation. (Luckey 1980, 1982, Wolff 1992, Macklis 1990). This, also, lead the United Nations Scientific Committee on the Effects of Atomic Radiation (UNSCEAR), to propose the linear nothreshold (LNT) theory in 1958, which has been adopted the international commission on radiation protection (ICRP) in 1959. The key statement of LNT theory is (UNSCEAR, 1958): Estimation of low dose effects of 
ionizing radiation is by linear extrapolation from effects observed by high doses. This concludes that, even very low doses of ionizing radiation produce some biological effect, i.e., there is no any safe dose.

The results of many studies do not support the LNT theory. This opposing evidence is argued in the following: I- Survival time: about $30 \%$ of the mice survived 30 days after the irradiation to a 8 Gy of X-rays, but, when mice irradiated, before 8 Gy-irradiation, with $50 \mathrm{mGy}$ of X-rays, the survival time increased to about $70 \%$ (Yonezawa et al. 1996).

II- Cancer occurrence in mice (Bhattarcharjee 1996), and workers in nuclear activities (Azzam et al. 1996). They showed that the latent period for development of acute myeloid leukemia (AML) considerably increased by the prior low radiation dose. Interestingly, according to Luckey, 30\% of all cancer deaths are premature and preventable by low-level ionizing radiation (Luckey 1994, 1997). In Canada, and UK, the number of deaths caused by cancer between workers at nuclear power plants was less than the national average (Kendal et al. 1992).

III- Epidemiological studies have indicated that radiation hormesis is really exist. Among survivors from Hiroshima and Nagazaki who received radiation doses lesser than $200 \mathrm{mGy}$, there was no increase in the number of entire cancer deaths. Deaths caused by leukemia was even lower in this population at doses below $100 \mathrm{mGy}$ than age-matched control partners (UNSCEAR,1994). Data from high level radiation areas from USA, India, China and Japan supports the radiation hormesis assumptions:

1- In USA, it was found that the mortality rate due to all tumors was lower in states with higher annual radiation dose. It was indicated that significantly, the total cancer mortalityis inversely correlated with background radiation dose (Cohen, 1993).

2-In India, it was observed that in areas with a high natural radiation level (HNRL), the incidence of cancer and also the death rate due to cancer was significantly less than similar non HNRL areas (Nambi and Soman 1987). 3- In China, it was showed that the death rate due to cancer was lower in an area with a relatively HNRL, while the control group who lived in a non HNRL area had a higher rate of death (Wei, 1990).

4- In Misasa, a spa region in Japan, with an average indoor radon level of $35 \mathrm{~Bq} / \mathrm{m}^{3}$, the lung cancer incidence was about $50 \%$ of that in a low-level radon region. In this high background radiation area, the mortality rate caused by all types of cancer was $37 \%$ lower (Mifune et al. 1992).

\section{Experimental}

External gamma dose-rate levels were measured in some of main hot springs in Jordan. (Fig. 1). The dose rates were measured twice, first by using a portable radiation measuring device (RADIAGEM 2000) which is a survey meter that includes an energy-compensated Geiger-Muller counter. The second measurements is carried out by an external probe connected to RADIAGEM 2000. The new CSP (Canberra Smart Probes) $S G$ - $1 R$ is designed for gamma radiation measurements. $S G-1 R$ which is a gamma probe with $\mathrm{NaI}(\mathrm{Tl}) 1^{\prime \prime} \times 1^{\prime \prime}$ scintillation detector, measures dose-rate equivalent.

\section{Results}

In the present study, the author would like to sum up all results obtained in a long work done in many hot spring sites in Jordan and gamma absorbed dose rates were measured and registered. These results are very similar to other results obtained using gamma spectroscopy, for soil samples from the same regions. These findings are presented in tables 1 , to 8 below. Registered gamma absorbed dose rates were measured in AlHammah spa (Al-Okour et al., 2013), Zara hot Springs(Ajlouni et al., 2012), the eastern seaside of the Dead Sea (Al-Saraireh et al., 2011), Afra Hot Springs (Ajlouni et al., 2009; 2010), North-Shuneh spa (Al-Okour, 2011) and Wadi Bin Hammad (AL-Amairyeen 2010).

Table 1.

Registered gamma absorbed dose rates in selected locations in Al hammah spa (Al-Okour et al., 2013).

\begin{tabular}{|c|c|}
\hline Location & Dose rate in air (nSv/h) \\
\hline Entrance & 90 \\
\hline Main Spring & $75-85$ \\
\hline Most-Heated Pool (Almaqla) & 115 \\
\hline Way (inside) & 90 \\
\hline Way (outside) & $120-175$ \\
\hline Out-Going Fluids & 180 \\
\hline Chalet In-Going Fluids & $500-580$ \\
\hline Chalet Channel & $200-500$ \\
\hline
\end{tabular}


Radiation Hormesis: High-Radiation Dose Equivalents in Hot Springs Enhancing Curative Practices

\begin{tabular}{|c|c|}
\hline Chalet Pool & 100 \\
\hline Chalet Other Areas & $100-200$ \\
\hline out-side areas & $30-70$ \\
\hline
\end{tabular}

Table 2

Dose rate in air from natural radionuclides in Zara hot Springs(Ajlouni et al., 2012).

\begin{tabular}{|c|c|}
\hline Region & Dose rate $\left(\mathbf{n G y h}^{-1}\right)$ \\
\hline Main street & 150 \\
\hline Walls & $\mathbf{1 5 0 - 2 5 0}$ \\
\hline Entrance & $\mathbf{2 3 0}$ \\
\hline Watercourse 1 & 350 \\
\hline Watercourse 2 & $\mathbf{5 6 0}$ \\
\hline spring & $\mathbf{6 5 0}$ \\
\hline Water sink & $\mathbf{3 0 0}$ \\
\hline Other points & $\mathbf{2 5 0 - 4 5 0}$ \\
\hline
\end{tabular}

Table 3

Registered gamma absorbed dose rates in the sampling points in the Dead Sea region (Al-Saraireh et al., 2011)

\begin{tabular}{|c|c|c|}
\hline Location & Characteristic of location & $\mathbf{n S v} / \mathbf{h}$ \\
\hline 1 & Fifa & $\mathbf{2 6 0}$ \\
\hline 2 & Safi & $\mathbf{1 0 5}$ \\
\hline 3 & Near Potash Company & $\mathbf{1 0 0}$ \\
\hline 4 & Esal & 60 \\
\hline 5 & Al-Mazrah & $\mathbf{6 0}$ \\
\hline 6 & $\mathbf{5 m}$ from Al-Mazrah to the north & $\mathbf{1 3 0}$ \\
\hline 7 & Dead Sea Health Centre & $\mathbf{4 5 - 8 5}$ \\
\hline 8 & Movenpick Hotel & $\mathbf{3 0 - 5 0}$ \\
\hline
\end{tabular}

Table 4

Registered gamma absorbed dose rates in different locations varies in its distance from the seaside (Dead Sea) in location 7 of Table 3. (Al-Saraireh et al., 2011)

\begin{tabular}{|c|c|c|c|}
\hline Location & $\begin{array}{c}\text { Distance from the } \\
\text { seaside (meter) }\end{array}$ & Characteristic of location & $\underline{\mathrm{nSv} / \mathrm{h}}$ \\
\hline 1 & 500 & Center Hall & 50 \\
\hline 2 & 400 & Near first swimming pool & 55 \\
\hline 3 & 300 & Near second swimming pool & 45 \\
\hline 4 & 200 & --- & 60 \\
\hline 5 & 100 & --- & 70 \\
\hline 6 & 1 & Near the water & 70-77 \\
\hline 7 & 1 & Top of the Black-Mud & 80-85 \\
\hline 8 & 1 & Top of the salt & 15 \\
\hline 9 & $\begin{array}{ll}--- \\
\end{array}$ & Water-body & $50-60$ \\
\hline
\end{tabular}

Table 5

Registered gamma absorbed dose rates in different locations varies in its distance from the seaside (Dead Sea) in location 8 of Table 3. (Al-Saraireh et al., 2011)

\begin{tabular}{|c|c|c|c|}
\hline Location & $\begin{array}{c}\text { Distance from the seaside } \\
(\text { meter })\end{array}$ & Characteristic of location & $\underline{\mathbf{n G} / \mathbf{h}}$ \\
\hline 1 & $\mathbf{7 0 0}$ & Hotel Hall & $\mathbf{4 0 - 5 0}$ \\
\hline 2 & 100 & -- & $\mathbf{3 0 - 4 0}$ \\
\hline 3 & 1 & --- & 50 \\
\hline 4 & ---- & Water-body & 50 \\
\hline
\end{tabular}

Table 6

Registered Gamma Absorbed Dose Rates in Selected Locations in Afra Hot Springs (Ajlouni et al., 2009; 2010).

\begin{tabular}{|c|c|c|}
\hline Location & Characteristics of Location & $\begin{array}{c}\text { Dose rate in air } \\
(\mathbf{n G y} / \mathbf{h})\end{array}$ \\
\hline Pool \#1 & Uncovered & $\mathbf{2 0}-\mathbf{5 0}$ \\
\hline
\end{tabular}




\begin{tabular}{|c|c|c|}
\hline Pool \#2 & Uncovered & $10-30$ \\
\hline Pool \#3 & Uncovered & $10-50$ \\
\hline Pool \#4 & Uncovered & $20-50$ \\
\hline Pool \#5 & Covered & $300-18000$ \\
\hline Pool \#7 & Sauna & $200-2000$ \\
\hline Fluids & Out-side & $20-100$ \\
\hline HLNRA & Rock cracks & $4 \times 10^{6}[1]$ \\
\hline Other & Rock cracks & $100-1000$ \\
\hline
\end{tabular}

Table 7

Registered gamma absorbed dose rates in selected locations in North-Shuneh spa (Al-Okour, 2011).

\begin{tabular}{|c|c|}
\hline Location & Dose rate in air $(\mathbf{n S v} / \mathbf{h})$ \\
\hline well pumps & $\mathbf{7 0 - 9 0}$ \\
\hline open-air swimming pools & $\mathbf{5 0 - 7 0}$ \\
\hline enclosed swimming pools & $\mathbf{5 0 - 6 5}$ \\
\hline family- enclosed pools & $\mathbf{6 0 - 7 0}$ \\
\hline cooling pool & $\mathbf{7 0}-130$ \\
\hline restaurant & $40-60$ \\
\hline out-going fluids & $\mathbf{2 0}-100$ \\
\hline Chalets & $40-60$ \\
\hline mini park and terrace & $40-50$ \\
\hline out-side areas & $\mathbf{1 0 - 5 0}$ \\
\hline
\end{tabular}

Table 8

Dose rate in air from natural radionuclides in Wadi Bin Hammad (AL-Amairyeen 2010).

\begin{tabular}{|c|c|}
\hline Region & Dose rate (nGyh-1) \\
\hline 1 & 15 \\
\hline 2 & 25 \\
\hline 3 & 20 \\
\hline 4 & 30 \\
\hline 5 & 60 \\
\hline 6 & 78 \\
\hline 8 & 82 \\
\hline 9 & 100 \\
\hline 10 & 1080 \\
\hline 11 & 1230 \\
\hline 12 & 1340 \\
\hline 13 & 2450 \\
\hline 14 & 2570 \\
\hline
\end{tabular}

IV. Discussion

Dose rates in hot springs in Jordan are classified as HNRL areas with higher radiation doses than those in other areas, these areas represent the water pools and source of thermal water. The national average ranges from 24 to $160 \mathrm{nGyh}^{-1}$, where most of areas in Jordan are very near to $24 \mathrm{nGyh}^{-1}$. The international annual effective dose is approximately $70 \mu \mathrm{Sv}$ (UNSCEAR, 2006).

Natural Radioactive isotopes emit different types of radiations with different energies in its decay chain. Since the most important contribution radiation is the gamma, we concentrated on the absorbed gamma dose rate in air. The external dose rate of the high radiation zone measured to be $650 \mathrm{nGy} / \mathrm{h}$. This was approximately more than twenty times greater than the dose rates obtained outside the hot springs zone. Further investigation should be done using gamma spectroscopy techniques based on $\mathrm{NaI}(\mathrm{Tl})$ and HPGe detectors.

Although the absolute method to describe the radiation hormesis still not identified, hormesis could be explained by one of the following theories: at molecular level: DNA repair, and free radical detoxification and at cellular level: stimulation of immune system. This becomes known as:

1- Low doses of ionizing radiation encourage the production of special proteins, which are involved in DNA repair processes. 
2- Low doses of ionizing radiation cause a transient inhibition in DNA fusion. This kind of inhibition of DNA synthesis would provide a longer time for irradiated cells to recover, and may produce free radical hunters, so irradiated cells would become radiation anti-sensitive, and not effected to any further radiation exposures.

3- Low doses radiation may excite the functions of the immune system. The first time to show that was in 1909, mice treated with low-level radiation were more resistant against bacterial disease.

Radiation hormesis promotes harmony with nature, where increased ionizing radiation, following exposure to low dose irradiation, in radiation-poor environments provides an increased lifespan, and improves quality of human life: health - growth, fertility, and immune and mental functions, with the knowledge that cancer-death rates, and all cause death decrease, as well as slowing down effects of aging.

Natural radiation doses, which gained exclusively from hot springs, always accompanied by other natural factors such as hot and mineral springs, mud baths and wraps, herbal baths, or by exposing to sun and dry climate and salt lakes like the Dead Sea in Jordan. This has its good effect on stimulating the psychological state of the patient and accelerating his recovery. In addition to these curative properties, these destinations are characterized by clean environment and non-crowded places, so human, patient or non-patient, gets relaxation and good look.

Other parties like travelling agencies, tour workers, airline companies, insurance companies, etc. will get great benefits from curative tourism.

\section{Conclusion}

Ionizing radiation is an important part of our universe, very essential for life and is needed for optimal health. Many people live in radiation-deficient environments.

LNT theory for radiation hazard exaggerates the radiation effects, and appears to be invalid in view of radiation hormesis and its strong facts. This is consistent with data from studies, as well as epidemiological observations on low-dose effects on animals or humans. Thus, LNT theory should be discarded and be replaced by scientifically, and logically justified theory, that origins for less radiophobia and unnecessary expenses. This was suggested by the author in many papers (Ajlouni, 2007, Ajlouni, 2010, Ajlouni, et al. 2010).

Curative tourist includes different therapeutic properties for curing many diseases and maintaining the general fitness of the body. The health benefits gained by visitors to hot springs and Dead Sea and residents living near to these areas according to the radiation hormesis model will be very helpful in initiate a great curative tourism industry, depending on hot springs distributed in all parts of the country as well as the great touristic and historic heritage available very near to each spa. At the same time, many economical associations will benefit from this promising curative industry.

\section{References}

[1]. Ajlouni, A., Al-Okour, A., and Ajlouni, A-W, High-Radiation Dose Equivalents in Jordanian Hot Springs. European Journal of Scientific Research,Vol.70 No.4 pp. 599-605, (2012)

[2]. Ajlouni, A-W., "Health Consequences of Nuclear Fission Products". J. Appl. Sci. Environ. Manage. Vol. 11(3) 11 - 14, (2007). www.bioline.org.br/ja

[3]. Ajlouni, A-W., and Al-Okour, A. "Fission Product Health Effects On Human Body". Pakistan Journal of Biological Sciences 10(19): 3405-3409, (2007). http://www.asninet.org/.

[4]. Ajlouni, A-W., "Deep Atomic Binding Hypothesis". ISBN: 978-3-8383-7930-2. LAP LAMBERT Academic Publishing AG \& Co., Saarbrücken Germany, 2010. https://www.lap-publishing.com/.

[5]. Ajlouni A-W., Abdelsalam M., Abu-Haija O., Joudeh B. New findings: a very high natural radiation area in Afra hot springs, Jordan. Radiation Protection Dosimetry, pp. 1-4. DOI:10.1093/rpd/ncp028, (2009).

[6]. Ajlouni A-W., Abdelsalam M., Abu-Haija O., Almasa'efah Y. Radiation doses due to natural radioactivity in Afra hot spring. Int. J. Low Radia., 7(1). DOI: 10.1504/IJLR.2010.032770, (2010).

[7]. Ajlouni, A-W., Yacoub S. Almasa'efah, and M. Abdelsalam. "Nuclear Fission Products: from Source to Environment". Journal of Environmental Science and Technology. 3(4): 182-194, (2010). DOI: 10.3923/jest.2010.182.194.

[8]. AL-Amairyeen H. Radiation doses due to natural radioactivity in Wadi Bin Hammad, Al-Karak, Jordan. International Journal of the Physical Sciences Vol. 5(9), pp. 1486-1488, (2010).

[9]. Al-Okour, A. Radiation Doses Due to Natural Radioactivity in North-Shuneh Hot Springs, Jordan European Journal of Scientific Research ISSN 1450-216X Vol.51 No.4, pp.582-586, (2011).

[10]. Al-Okour, A. Ajlouni, A-W., Ajlouni, A.and Shakhatreh S., Radiation Doses due to Natural Radioactivity in Al Hammah Hot Springs, Jordan. Contemporary Engineering Sciences, Vol. 6, 2013, no. 3, $127-134$, (2013).

[11]. Al-Saraireh, Sh., Ajlouni, A-W., Wardat, M, AL-Amairyeen H. "Registered gamma absorbed dose rates in the Dead Sea region". Canadian Journal of Pure and Applied Sciences, Vol. 6, No. 2, pp. 2017-2022, June (2012).

[12]. Azzam E.I., Low dose ionizing radiation decreases the frequency of neoplastictransformation to a level below the spontaneous rate in C3h 10T1/2 cells, Radiation Research, Vol. 146, No.4, pp. 369-73 (1996).

[13]. Bhattarcharjee D., Role of radioadaptation on radiation-induced thymic lymphoma in mice.Mutation Research, 358, 231-235 (1996).

[14]. Bruce M., Radiation hormesis after 85 years, Health Physics Society Newsletter(1987).

[15]. Cohen, B. L., Relationship between exposure to radon and various typesof cancer, Health Physics, Vol. 65, No. 5, pp. 529 (1993).

[16]. Harahsheh S. Curative Tourism in Jordan and its Potential Development. MA thesis in European Tourism Management. Bournemouth University, United Kingdom, , (2002). 
[17]. ICRP, Recommendations of the international commission on radiological protection,Publication No. 1, Pergamon press, London, (1959).

[18]. Kendal,G. M., Muirhead, C. R., Macgibbon, B. H., Oagan, J. A., First Analysis of the national registry for radiation workers; Occupational exposureto ionizing radiation and mortality, NRPB, Chilton, Didcot, U.K., RPB-R251, (1992).

[19]. Kumatori,T., Ishihare,T. and Herashima,K., "Follow-Up Studies Over a 25-Year Period on the Japanese Fishermen Exposed to Radioactive Fallout in 1954", In: "The Medical Basis for Radiation Accident Preparedness", Editors: Hubner K. , and Fry, A., Elsevier/North-Holand, New York, International Council of Scientific Union, (1980).

[20]. Luckey T.D., Hormesis with ionizing radiation, CRC press, Baca Raton (1980).

[21]. Luckey T. D.,Physiological benefits from low levels of ionizing radiation, Health Physics, Vol. 43, pp. 771-789, (1982)

[22]. Luckey T. D., Low dose radiation reduces cancer deaths, Radiation Protection Management, Vol. 11, No. 1, pp. 73-79 (1994).

[23]. Luckey T. D., A rosseta stone for ionizing radiation; radiation protectionmanagement, Vol. 14, No. 6, pp. 58-64, (1997).

[24]. Macklis R. M., Radithor and the era of mild radium therapy, JAMA,Vol. 246, No. 5, pp. 614-18, (1990).

[25]. Macklis R. M. and Bresford B., Radiation hormesis, J Nucl. Med.,Vol. 32, pp. 350-359, (1991).

[26]. Mifune, M., Sobue, T., Arimoto, H., Komoto., Y., Kondo S., and Tanooka,H., Cancer mortality survey in a spa erea (Misasa, japan) with a high radon background, Japanese journal of cancer research, Vol. 83, No. 1, (1992).

[27]. UNSCEAR, Report of the United Nations scientific committee on the effects of atomic radiation, (1958).

[28]. UNSCEAR. Sources and effects of ionizing radiation, New York, (1994).

[29]. UNSCEAR. Effects and Risks of Ionizing Radiations (New York: United Nations), (2006).

[30]. Wei L., Epidemiological investigation of radiological effects in highbackground radiation areas of Yangiang China, J. radiation research, Vol.31, pp. 119-136 (1990).

[31]. Wolff S., Failla Memorial Lecture. Is radiation all bad? The search for adaptation. Radiat Res. ;131(2):117-23, (1992).

[32]. Yonezawa M., Misonoh J, Hosokawa Y., Two types of X-ray induced radioresistance in mice, presence of 4 dose ranges with distinct biological effects, Mutation Research, 358, 237-243, (1996).

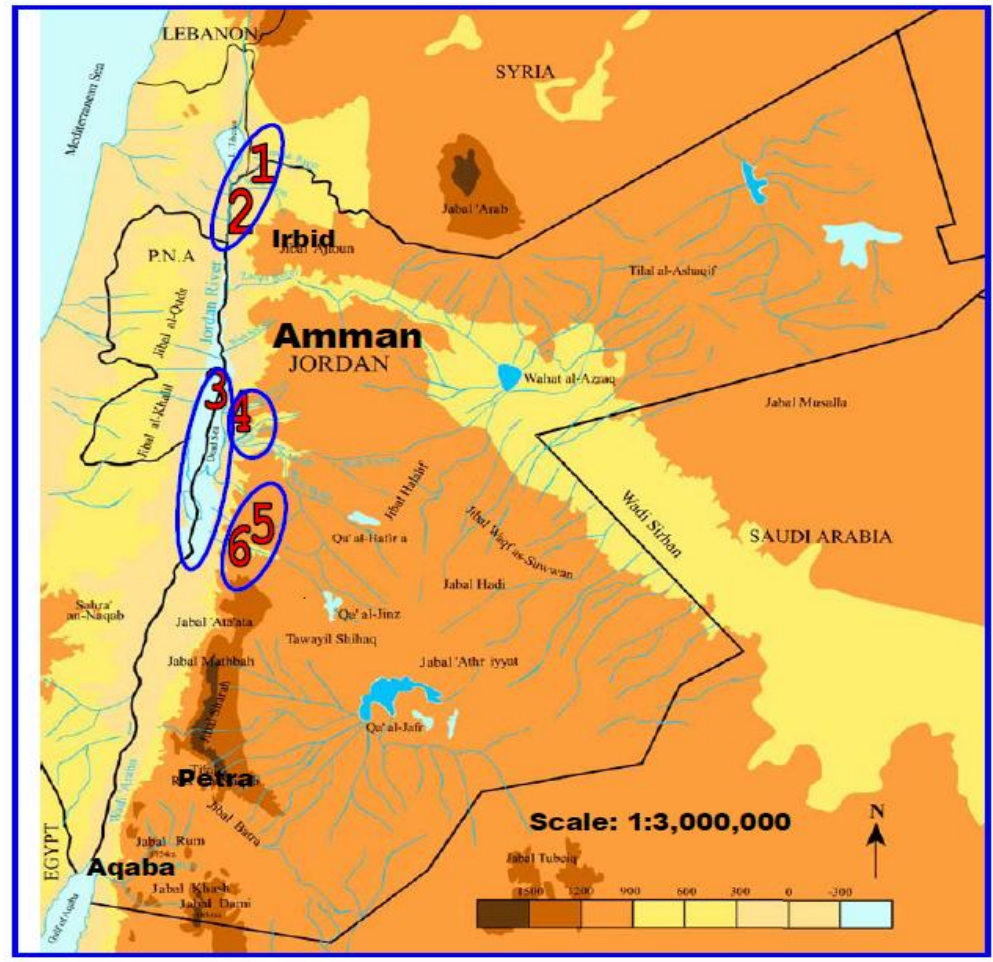

Figure 1. Map of the main hot springs in Jordan:1: Al Hammah; 2: North-Shuneh ; 3: The Dead Sea; 4: Ma'in; 5: Al Barbaitah; 6: Afra. (Source: http://www.tourism.jo/, Harahsheh, 2002) 